\title{
紙の静電 調湿装置について
}

日本ハルプ工業株式会社研究所 川瀬馨

印刷用紙あるい性加工用紙などで，実用的汇最も問 題之なる性質の一つに紙ぐせがある。特に大気湿度の 変化にともなら紙の伸縮によるトラブルを解決するた あには，製紙工程で加湿装置を設けて調湿する必要性 ぶ増大している。

調湿の目的惊，(1)平衡水分の保持，(2)紙匹水分の均 一化，(3)乾燥応力の緩和に㐫る。このために，従来使 用されている方法には次のごときものがある。

1. 空気湿度調湿法

2. 凝縮加湿法

当社米子工場では，新しい試みとしてコーターに連 続してポール型静電噴霧式加湿機を設置し, 今春来順 調に操業を続けている。
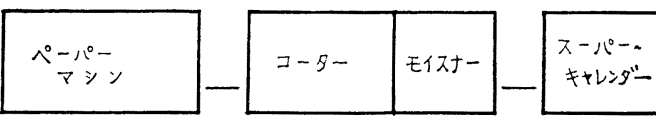

図 1 米子工場の工程

米子工場の工程は図 1 であり，オフコーターの次に 連続して静電加湿機（モイスナー）があり，これによ り加湿後スーパキャレンダー処理を行なって塗工紙を 製造している。

A. Pohl(1) らの報告にもあるが，この加湿機の模式 図を示すと図 2 である。水タンクからヘッド美あるい はノズル吸引力によって水が供給される。同時に，ブ ローアーから压縮空気が送られ，水は微細粒子となっ て噴霧される。この時，ノズルとロール間汇高電圧が

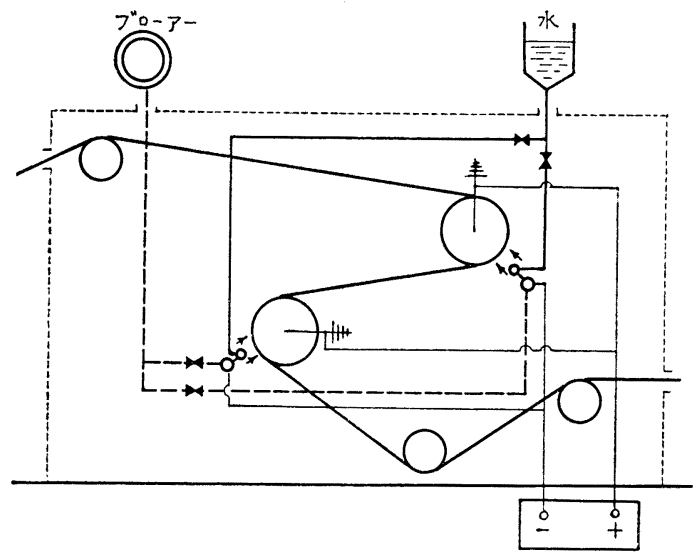

図 2 モイスナー模式図
印加される(ノズル側が負)。高電圧の印加により水粒 于はさらに微細化され，肉眼的には薄い霧状になって, ロール面へ集中することが観察される。水量は元バル ブおよび各ノズルのバルブで調節される。風量はバル ブによって風圧を一定 $\left(0.7 \sim 0.9 \mathrm{~kg} / \mathrm{cm}^{2}\right)$ にしてコン トロールし，印加電压は $100 \mathrm{kV}$ である。ノズルとロ 一ル間距離は $200 \mathrm{~mm}$ ，ノズル先端はロール面に直角 に設置し，表裏各々に 4 段のノズル群が配置される。

この静電噴霧加湿法は A. Pohl らにより研究され 完成されたものである。彼らの報告によれば，圧縮空 気によって噴霧される水粒子の大ささは $10 \sim 20 \mu て ゙$ ある。電圧印加により, 水滴は荷電体となってより微 細な粒子 $(0.5 \sim 1 \mu)$ に崩壊し，この電荷をおびた静 電エアゾルは再結合しにくく安定化さ カッター れる。通常紙の毛細管隚の大ささは, $0.5 \sim 2 \mu$ であるから，この微細水粒子 は紙層内に有效汇浸透吸着される。同 時汇荷電体は電界の方向隹速され，

ロール面集中する。

この加湿法の特長をあげれば次のごとくである。

1. 高速処理が可能である。

2. 連続処理が可能である。

3. 設備はコンパクトで小さな床面積でよい。

4. 水分の均一化が容易である。

ノズル部分のみを拡大して図 3 に示す。ノズルは片 面で 4 列，両面で合計 8 列である。このうち 1 列の， ズル群は 10 セクションに分れており，1列汇約 100 本 のノズルが配置されている。幅方向の原紙水分バラッ

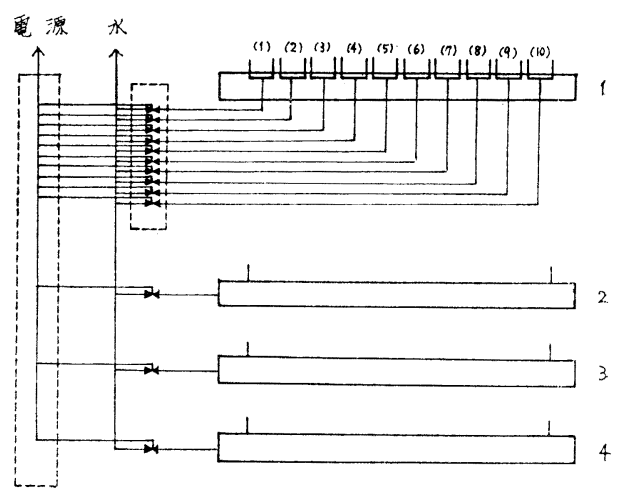

图 3 ノズル配置図 
キに応じて各セクションが自動的に断続され る。他の 3 列はいずれも各々が 1 セクション であり，流れ方向の原紙水分のバラッキに応 じて 1 列ごとに給水が自動的㹸断続されるよ

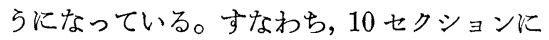
分れている1段のノズル群で幅方向の水分が 管理され，他の段のノズル群によって流れ方 向の水分の均一化が行なわれる。一般に, ペーパーマシンで高水分に保って，乙かも幅 方向の水分を均一にすることは非常に困難で ある。よって低水分で比較的均一飞乾燥して から，均一汇水分を付加することが均一な高 水分の紙とするためには有効である。また湿 紙匹を低水分まで急速に乾燥し，さらに加湿 水よって幹燥時の歪みを取り去ることが紙の 寸法安定性にはのぞましい条件である。

加湿量は原紙米坪，マシン速度，水量によ って変化するが，実用的汇水分約 $3 \%$ 位ま での加湿が可能である。

以上のことが，実際のマシン操業を通じて明らかに なってきたが，たまたま東英電子株式会社が同様の効 果を狙いとした装置を開発し，そのテストマシンの試 験が当社に依頼されてきた。そこで，当研究所でこの 装置を使用して，静電調湿関する一連の基礎的検討 を行なった。

実験方法は次のごとくである。

1. テスト機仕様

$\begin{array}{lrl}\text { 紙 幅 } & 580 \mathrm{~mm} \text { 以内 } \\ \text { 紙行速度 } & 500 \mathrm{~m} \text { 以内 } \\ \text { 静電 压 } & 100 \mathrm{kV} \\ \text { 風 压 } & 0.9 \mathrm{~kg} / \mathrm{cm}^{2} \text { 以下 } \\ \text { ノズル } & \text { 片面 } 2 \text { 段 }\end{array}$

2. 水粒子径の測定（電圧なしの状態）

噴霧された水粒子を，プレパラート上に塗布 した適当な粘性の油中に捕集しこれを顕微鏡 写真にとって粒径分布を測定。

3. 水分分布の測定

着色水（赤色）を噴霧し紙上の色濃度をデン シトメーターで測定。

4. 伸縮性の測定

TAPPI 伸縮度測定機により湿度変化にとも なら伸縮性の変化, および一定湿度におる汗る伸 縮の径時変化を測定。

まずテスト機による加湿量の測定結果（実測）を図 4 亿示す。 $\mathrm{P}$ 型と $\mathrm{D}$ 型の 2 種のノズルを 2 段として $10 \mathrm{cc} / \mathrm{min}$ の流量, $0.9 \mathrm{~kg} / \mathrm{cm}^{2}$ の風圧で噴霧した結果

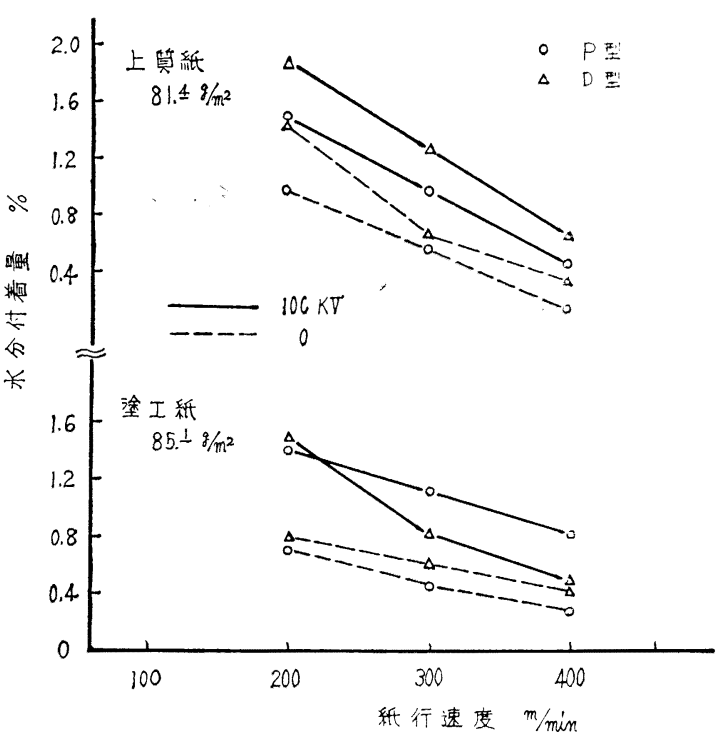

図 4 静電噴霧による加湿量の変化 である。紙行速度を $200 \sim 400 \mathrm{~m} / \mathrm{min}$ 亿変化し, 水分 5.0 5.5\%の上質紙持よび塗工紙を使用した。加湿量 は紙行速度に比例することは当然である。100kVの電 圧印加により加湿量は $2 \sim 3$ 倍となる。加湿量はP 型 ノズルと D型ノズルでは差が認められない。また塗工 紙は上質紙より加湿量がやや少ないようであるが，加 湿自体には水粒子の紙層内浸透流必らずしも必要では ないとい觉。

表 1 噴霧水粒子の大きさ

\begin{tabular}{|c|c|c|c|c|c|c|}
\hline ノズル & \multicolumn{2}{|c|}{$\mathrm{P}$ 型 } & \multicolumn{2}{|c|}{ T-502型 } & \multicolumn{2}{|c|}{$\mathrm{T}-10$ 型 } \\
\hline $\begin{array}{l}\text { 水 } \text { 量 } \\
\mathrm{cc} / \mathrm{min}\end{array}$ & 15 & 10 & 15 & 10 & 15 & 10 \\
\hline$\mu$ & 21.2 & 17.8 & 19.4 & 15.3 & 19.9 & 16.7 \\
\hline$\sigma \quad \mu$ & 5.1 & 4.2 & 4.4 & 3.5 & 4.2 & 5.6 \\
\hline
\end{tabular}

風圧 $0.7 \mathrm{~kg} / \mathrm{cm}^{2}$

電圧 0

前述したように，マクロな水分分布はノズル本数の 自動的コントロール，水量の調節により管理される。 しかし加湿水分のミクロな均一性はノズルの構造や噴 霧条件により支配されることが明らかとなった。すな わち荷電により水粒子の方向性は規定され，微細粒子 となるが，その状態はノズルの性能により著しく変化 する。

電圧をかけない時の噴霧水粒子の粒径分布を実測し

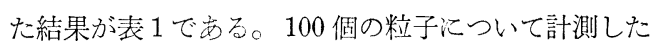

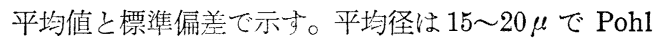
の報告にほぼ一致する。ノズル種類により粒子径の異 
ることは当然であるが，T型は $\mathrm{P}$ 型よりやや小さいよ うである。粒径のバラッキは T-502が最も小さい。水 量によっても粒径は変化する。一般に水量が増せば粒 径も大きくなる。バラッキも水量の増加につれ大きく なるのが普通であるが， T-10 型では $10 \mathrm{cc} / \mathrm{min}$ にお 汀るバラッキは $15 \mathrm{cc} / \mathrm{min}$ の場合よりも大きく逆であ る。電圧を印加した時の粒径は測定していないが，基 本的には均一で微細な粒子を噴霧することが肝要であ る。加湿状態は基本的にはノズル特性によって決定さ れ, ノズル性能が不適当であると, 粒子平均径は小さ くても, 紙表面に付着した場合に粗粒子となって斑点 状になったり，またノズル間に広がらないで縞状の水 分分布となって小さな波打ち，乙わの原因となる。

図 5 は 1 本のノズルを噴霧した時の状態, 図 6 は多

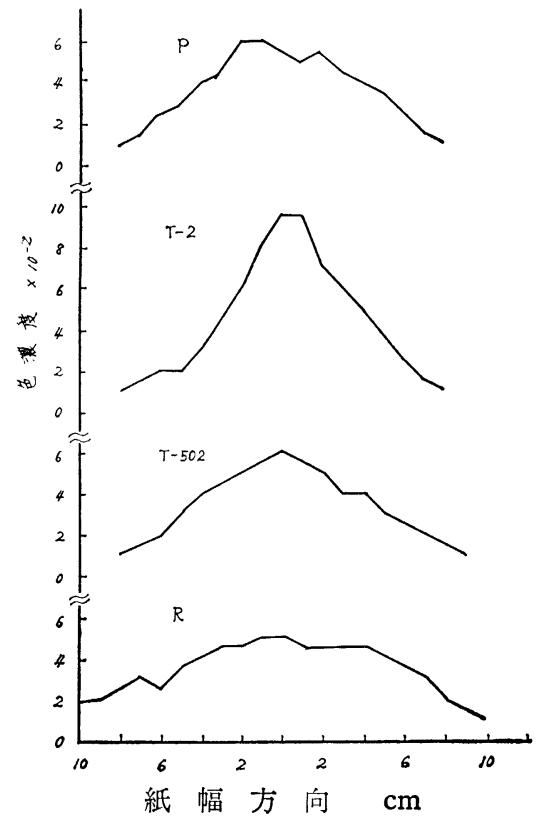

図 5 ノズル種類と水分分布（1本）
数本のノズルを使用した時の付着水の分布を色濃度で 代用したものである。図5でノズルの種類により水分 の付着状態が非常に異なることが明瞭である。 $\mathrm{P}$ 型お よび T-502 型は理想的な分布で，T-2 型は水が中心 部に集中し， R 型はあまりに広がりすぎる状態である。

上述の $\mathrm{P}$ 型と $\mathrm{T}-2$ 型を等間隔に多数本ならべて着 色水を噴霧し, 紙の幅方向の濃度変化を図示したもの が図 6 である。 $\mathrm{P}$ 型では幅方向の濃度の変化が非常に 小さく, 全面に均一に水分が付着していることを示す。 一方， T-2 型の場合には濃度変化が大さく，ノズル 中間部分は汪とんど着色されていない。したがって， 紙上では縞状の分布となって表われる。これは水粒子 の噴射方向が重要であるためで，T-2 型に拈いては 水粒子が直進的に噴射されるためである。

ミクロな水分分布はノズル特性と共に噴霧条件すな うち水量, 風量, 風圧, ノズル角度, ノズル間隔, ノ ズルとロールの距離などにも影響される。これらのう

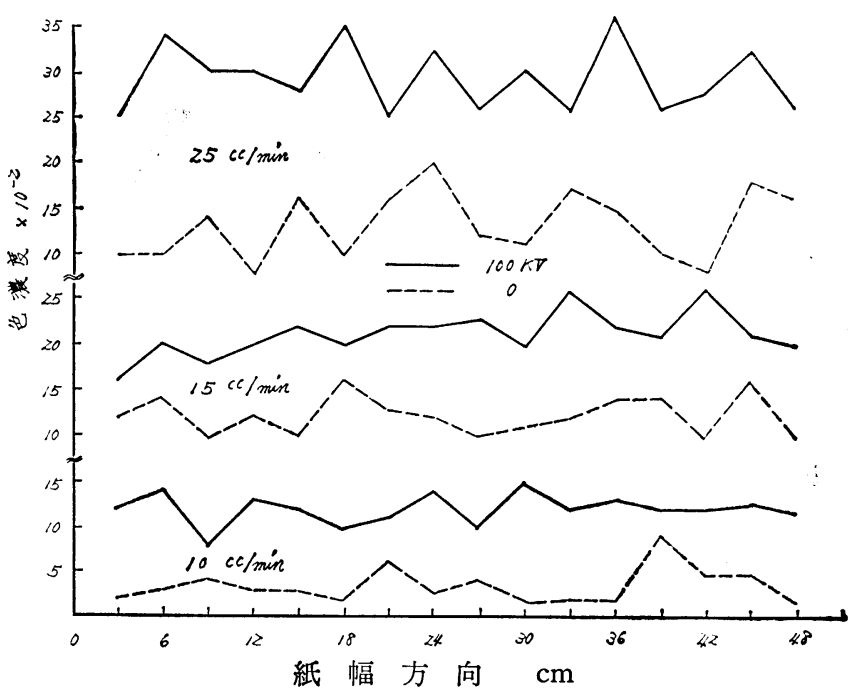

図 7 水量と水分分布の関係

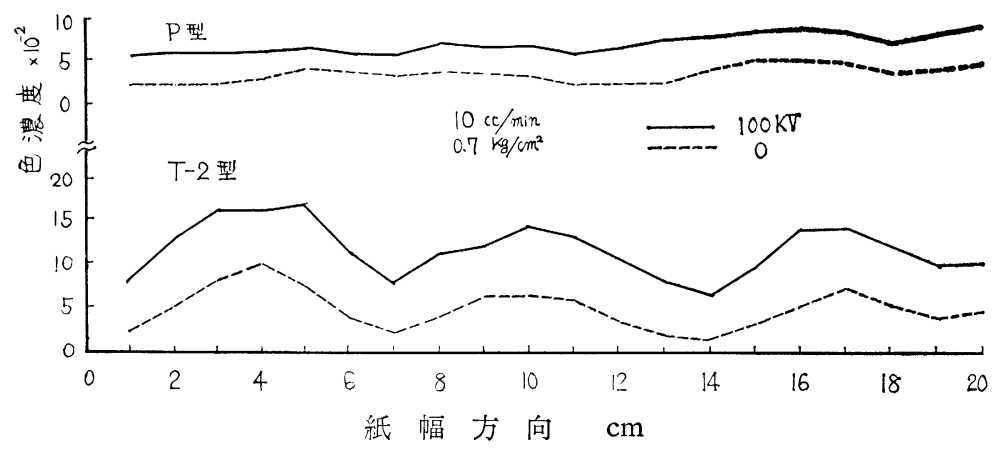

図 6 ノズル種類と水分分布 (多数本)
ら，水量之風圧の要因が重要 である。

図 7 亿水量の影響を示す。 水量と粒子径の関係は表 1 で 示したが，多数本のノズルで $100 \mathrm{kV}$ の電圧を印加した $\mathrm{P}$ 型 ノズルでは, 水量の増加につ れ，粒子径は大きくなって粗 大粒子の付着が目につき，ま た加湿量が増すと共に縞状に 分布する傾向が強くなる。 ズル特性に応じて最適の水量 


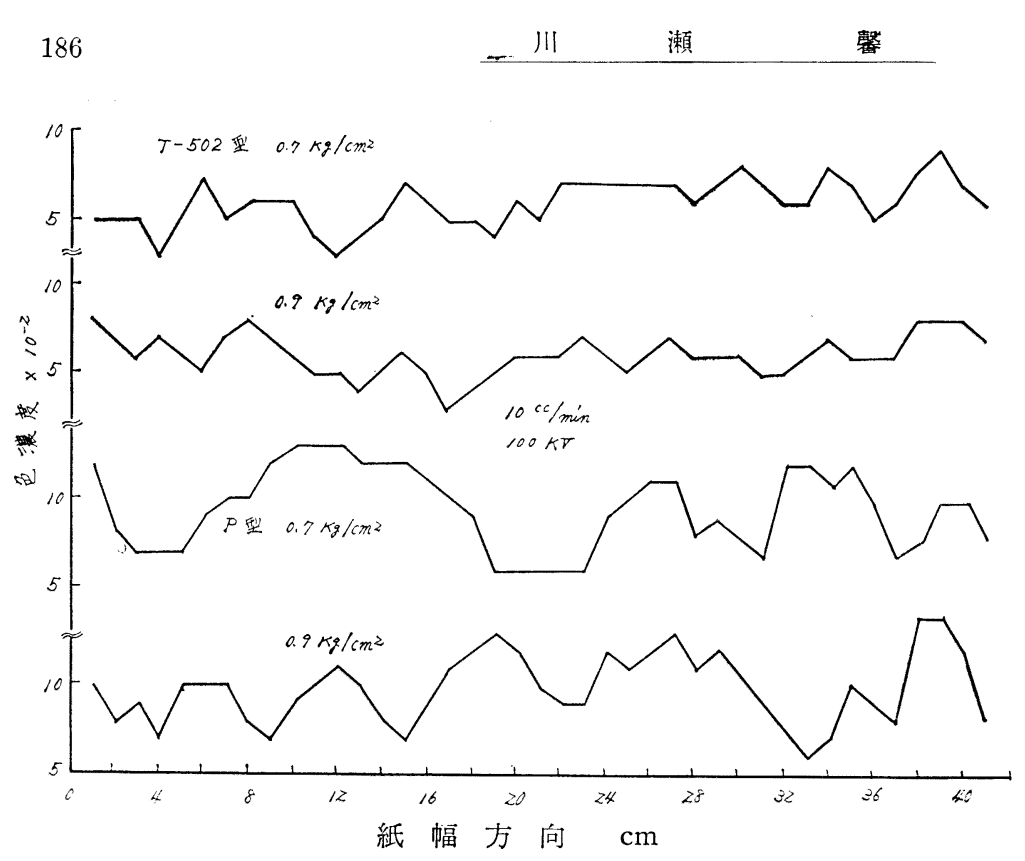

図 8 風圧之水分分布の関係

で噴霧することが必要であり，水量がすくないと所定 の加湿量とするにはノズル本数をふやさね水ばならず， 水量が過大になると, 水分分布は不均一で粗大水滴に よる斑点状の付着も多くなる。一般的には $10 \sim 15 \mathrm{cc} /$ minの水量が適当である。

$\mathrm{T}-502$ 型と $\mathrm{P}$ 型ノズルを用い，風圧 $0.7 \mathrm{~kg} / \mathrm{cm}^{2}$ と $0.9 \mathrm{~kg} / \mathrm{cm}^{2}$ の比較を行なった結果が図 8 である。 $\mathrm{T}$ 一 502 型では風圧の影響は表われないが，P型ノズルで は風圧を $0.7 \mathrm{~kg} / \mathrm{cm}^{2}$ 亿さげると, 縞状の水分分布と なり，粗大粒子が多くなることをしめしている。

その他の賴霧条件とあわせて，すぐれた特性のノズ ルで適当な条件を選定することがミクロな水分分布を 均一とし，小さなしわや波打ちの発生を防ぐために重 要である。

ノズルがー定であれば加湿量は紙行速度に比例する ことは当然であるが，本テスト機で片面加湿の場合に， $3 \%$ 以上の加湿を一度に行なら之過㮃の水分が紙の裏 側にまで不均一に浸透し，斑紋となって表方れ，紙面 に細い凹凸を生じる。片面加湿でこの影響が完全に認 められない水分付着量の限界は $2 \%$ ある。ししたがの て両面加湿であればやはり $3 \%$ 以内の加湿が実用的に は安全であるうと判断される。

つぎに静電加湿による紙ぐせあるい性摍性に対す る効果であるが，これは従来の凝縮式加湿法などによ るものと根本的には同様であるといえる。しかし乾燥 直後の紙滛間的汇紙層内部紊で均一に水分を吸収さ せることは紙ぐせに対してきわわて効果的であると考 えられる。実際に当社の塗工紙は印刷作業性の面で若
干の難点が㐫り, 需要家各位 にも御迷惑をかけていた。こ の加湿処置を運転後の試料仁 関しては実用印刷上の問題が 著しく改善されたとの評価を えている。

$52.4 \mathrm{~g} / \mathrm{m}^{2}$ の上質紙に加湿 した場合の伸縮性に対する影 響を検討した。加湿量は紙行 速度によりコントロールした。 加湿直後の試料弚のま宗の伸 縮性と加湿後 $65 \% \mathrm{RH}, 20^{\circ} \mathrm{C}$ で3 日間さらに調湿してから の伸縮性を比較した。

伸縮性を考光る場合に，緍 に連続的な湿度変化を市た总 た時の状態と，一定湿度での 伸縮の変化の二面がある。連 続的交湿度変化での紙の伸縮性を観察するためには， 予め低湿度から高湿度に変化して十分に試料を伸長し てから連続的な湿度変化によりとステリシスを学かく。 したがってこの場合には紙水分の影響を比較的小さく した状態での紙の基本的な伸縮性を示す。一方，一定 湿度に放置された時の紙の伸縮は平衡水分之の差に上 る紙の吸脱湿にもとづく伸長, 収縮である。すなう方 実用的には後者の過程が非常に問題となる。

表 2 加湿に上る伸縮性の変化

\begin{tabular}{|c|c|c|c|c|}
\hline & $\begin{array}{c}\text { 紙行速度 } \\
\mathrm{m} / \mathrm{min}\end{array}$ & 水 $\%$ 分 & 伸長率 & $\begin{array}{c}\text { 収縮 率 } \\
\%\end{array}$ \\
\hline \multirow{3}{*}{$\begin{array}{l}\text { 未 } \\
\text { 調 } \\
\text { 湿 }\end{array}$} & 厚 紙 & 5.4 & 0.224 & 0.252 \\
\hline & 180 & 7.0 & 0.216 & 0.246 \\
\hline & 100 & 8.8 & 0.226 & 0.239 \\
\hline \multirow{3}{*}{$\begin{array}{l}\text { 調 } \\
\text { 湿 }\end{array}$} & 厚 紙 & 6.9 & 0.211 & 0.249 \\
\hline & 180 & 7.2 & $0 \cdot 244$ & 0.244 \\
\hline & 100 & 7.7 & 2.234 & 0.234 \\
\hline
\end{tabular}

$\begin{array}{ll}\text { 伸 縮 } & 50 \sim 65 \% \mathrm{RH} 20^{\circ} \mathrm{C} \\ \text { 調 湿 } & 65 \% \mathrm{RH}, 20^{\circ} \mathrm{C} 3 \text { 日 } \\ \text { ノズル } & \mathrm{T}-502 \text { (片面) } \\ \text { 厚 紙 } & \text { 上質紙 }\left(52.3 \mathrm{~g} / \mathrm{m}^{2}\right. \\ \text { 水 量 } & 10 \mathrm{cc} / \mathrm{min} / \text { 本 } \\ \text { 風 压 } & 0.7 \mathrm{~kg} / \mathrm{cm}^{2} \\ \text { 電 压 } & 100 \mathrm{kV}\end{array}$

表 2 で加湿後未調湿試料の 50 0 65\% RH の範团の 伸縮には汪と儿ど差が認められない。しかし，加湿後 さらに調湿した試料の伸縮は加湿によりやや小さく なっている。抄造後数カ月をへた試料であるため,す でにかなりのシーズニングが進行しており, 加湿処理 


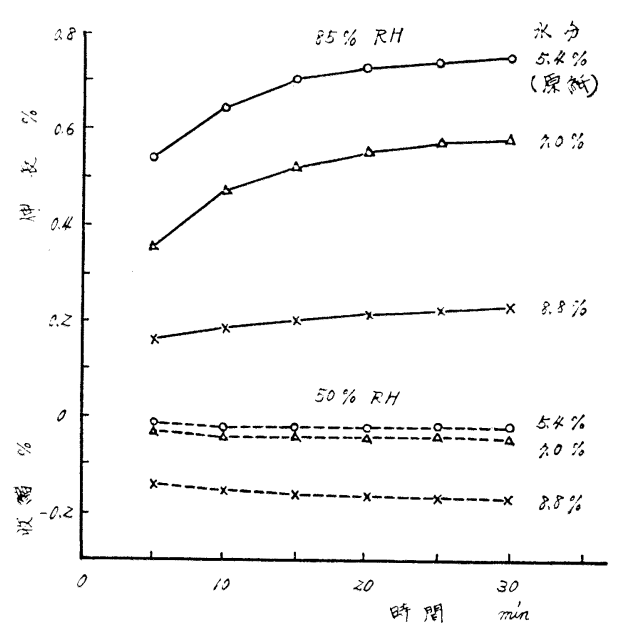

図 9 - 定湿度に起方伸縮（加湿直後）

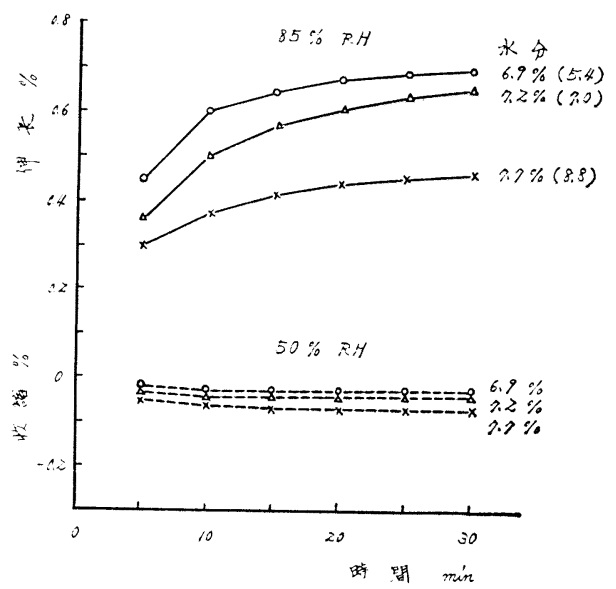

図 10 一定湿度に护方伸縮（加湿後調湿）
による乾燥応力の緩和の効果が僅かしか表われてこな W。

前述したが，実際上はある湿度の大気中に紙がおか れて紙葉の変形がおこる。この大気湿度に対応する平 衡水分を紙が保持していれば相対的な伸縮は起こりえ ない。すなわち構造的な伸縮性を小さくする以上に紙 水分を平衡水分に近づけることが極めて有効となって くる。この関係が図 9,10 である。図 9 は加湿直後の 試料, 図 10 は加湿後さらに調湿した場合である。伸 縮は非常に短時間のうちにおこり, 吸湿による伸長が 脱湿による収縮より実用的には大きいことを示してい る。また表 2 にるように, 加湿量と共に調湿後の平 衡水分は高くなっている。このために調湿後でも加湿 により $85 \%$ RHに沶ける伸長は小さくなる。

加湿により紙ぐせを改善する効果としては

1. 平衡水分に近づけることにより，大気湿度との 差にもとづく吸湿伸長を小さくする。

2. 水分の均一化による紙葉の部分的変形を防止す る。

3. 乾燥応力を緩和し基本的な伸縮性を小さくする。 が期待される。特にこの種の加湿法によれい゙，水分を 高水準でコントロールすることが比較的容易であるか ら，用紙の使用条件に応じた水分率の設定によって実 用的な伸縮性の低下を可能とする。

本研究に使用したテストマシンは東英電子工業株式 会社で設計製作され，ノズルの設計開発は東京大学工 学部豊田研究室が担当された。東英電子およご豊田研 究室に深く敬意を表する。

1. W. Brecht and A. Pohl

\section{参考文 献}

Das Papier 14(10a) 590(1960)

(原稿受付 昭41.12.23)

\section{○ 海外新刊紹介}

Gunnar Gavelin : Science and Technology of Mechanical Pulp Manufacture 本文 245 頁; 八 ードカバー (ビニール装) 1966 年版 7.50 \$ L Lockwood Publishing Co., Inc.,

著名はその名の示するうに元来はスエーデン人で Swedish Paper \& Groundwood Mills の General Laboratory に在勤中の実地経験と（アメリカなどの 若干の生産会社その他の) 研究所のエクスパート連か ら提供された資料を基礎にして執筆した。1）木材摩 解の理論と実際，2）機械的パルプ用グラインダーの
再評価，3）摩诉恷の変数, 品質に及ぼす乞の効果, 4 ）パルプストーンの各章はグラインダーストーンに よる在来の G P の生産と品質に及ぼす諸要因を論じ, 5) G P 品質の測定， 6) 機械的パルプの品質問題の 3 章では測定のほかにコントロールを含めて取扱い, 最後の 2 章 (チップからの機械的パルプの現状; 化学 的一機械的パルプ化法) では, 今や世界の機械的パル プの $5 \%$ に相当する 100 万トンの処理を引受けている 市販リファイナー各種その他の項目について論じてい る。第 1 章の概観的記事は Dr. Douglas Atack（カ ナダ国立木材繊維科学部長）が担当している。

(松井) 